\title{
Educate to Detect: Conducting First Detector Training in Florida 1
}

\author{
Amanda Hodges, Jennifer Gillett-Kaufman, Carrie Harmon, Aaron Palmateer, Pamela Roberts, \\ Adrian Hunsberger, Sylvia Shives, Theresa Friday, and Jiannong $\mathrm{Xin}^{2}$
}

\section{Who is a First Detector?}

A First Detector is anyone who might encounter an unusual, exotic pest during the course of their daily activities. Examples of First Detector groups include:

- County Extension Agents

- Crop Consultants

- Growers

- Master Gardeners

- Master Naturalists

- Homeowners

- Pest control operators and others involved in plant management
- Florida Department of Agriculture Inspectors

\section{Who is a First Detector Educator?}

First Detector Educators are primarily extension specialists and county extension educators. In some instances, crop consultants or others may also serve as First Detector Educators.

\section{What is a First Detector Training?}

The mission of the NPDN First Detector training program is to promote the early detection and proper identification of potentially devastating exotic species through a coordinated extension education effort. First Detectors, through the Cooperative Extension Service, are the eyes and ears of the NPDN program. Much of the activity of First Detector training is conducted locally, but is also occasionally available on a regional basis. The Florida or local component of the Southern Plant Diagnostic Network (SPDN) is

1. This document is ENY-501 (IN788), one of a series of the Entomology \& Nematology Department, Florida Cooperative Extension Service, Institute of Food and Agricultural Sciences, University of Florida. First published: December 2008. For more publications related to horticulture/agriculture, please visit the EDIS Website at http://edis.ifas.ufl.edu/.

2. Amanda Hodges, Assistant Extension Scientist, Associate Director-SPDN, Jennifer Gillett-Kaufman, Assistant Extension Scientist, Entomology and Nematology Department, Gainesville FL; Carrie Harmon, Assistant-In, Extension Scientist, Associate Director-SPDN, Plant Pathology Department, Gainesville FL; Aaron Palmateer, Assistant Professor, Plant Pathology Department, Tropical Research \& Education Center, Homestead, FL; Pamela Roberts, Associate Professor, Plant Pathology Department, Southwest Florida Research and Education Center, Immokalee, FL; Adrian Hunsberger, Urban Horticulture Extension Agent, Miami-Dade County; Sylvia Shives, Ornamental Production Extension Agent, Manatee County; Theresa Friday, Environmental Horticulture Extension Agent, Santa Rosa County; and Jiannong Xin, Associate in Information Technology, Office of Information Technology, Gainesville FL.

The Institute of Food and Agricultural Sciences (IFAS) is an Equal Opportunity Institution authorized to provide research, educational information and other services only to individuals and institutions that function with non-discrimination with respect to race, creed, color, religion, age, disability, sex, sexual orientation, marital status, national origin, political opinions or affiliations. U.S. Department of Agriculture, Cooperative Extension Service, University of Florida, IFAS, Florida A. \& M. University Cooperative Extension Program, and Boards of County Commissioners Cooperating. Millie Ferrer, Interim Dean 
the Florida Plant Diagnostic Network (FPDN) http://fpdn.ifas.ufl.edu/. The University of Florida also serves as the regional center for the SPDN.

First Detector Training is at least a two hour event where a First Detector Educator provides training to future First Detectors. The training provided in these sessions can include information on many topics, and it is largely based on the needs of the group being trained. Information usually includes the mission of the National Plant Diagnostic Network (NPDN), information on collecting and submitting samples, and raises awareness concerning new pests of concern, for the detectors and a hands-on activity (for more please see section entitled What Content Does First Detector Training Cover?).

\section{Why Conduct a First Detector Training?}

Florida's agricultural commodities and natural areas are continually threatened by non-native plant pest introductions. Approximately 12 new, non-native arthropod pests establish annually in Florida (Frank and Thomas 2004). Although not all of these pests are problematic from an exotic species perspective, some examples of recent damaging invaders have included citrus canker, citrus greening, red palm mite, pink hibiscus mealybug, chilli thrips, and cycad scale. Management or eradication of such introductions depends on early detection and accurate diagnosis. First Detector training is an opportunity to promote awareness and proper diagnosis of pest problems.

\section{Incentives for First Detectors - Why Complete Training?}

The educational value of the material is the primary benefit to completing First Detector training. First Detectors also receive a certificate of course completion. Educators organizing First Detector training may apply for CEUs for their clientele as an added incentive. First Detectors receive the NPDN First Detector Newsletter, edited by Carrie Harmon clharmon@ufl.edu, and pertinent pest alerts.

Through awareness and reporting of suspect high-risk samples, trained First Detectors are helping to protect their local environment and reduce economic impacts caused by invasive, unwanted pests.

\section{What Content Does First Detector Training Cover?}

NPDN First Detector training is a part of a national and southern regional program. Core content includes the following:

- Mission of the NPDN

- Monitoring for High Risk Pests

- Submitting Diagnostic Samples

In addition to the core content of First Detector training, the following modules are also often covered:

- Diagnosing Plant Problems

- Photography for Diagnosis

Diagnosing Plant Problems focuses on the signs and symptoms of common plant pathogen and insect damage. It is important for a First Detector to understand the common signs of plant damage in order to detect an abnormal or unusual pest. Although training on other plant-related diagnostic topics occurs, a majority of NPDN First Detector training programmatic activities have focused on plant pathogens and arthropods. In addition to these pest groups, many NPDN labs also handle nematode samples, but weed identification may be limited.

Photographs often allow an extension specialist or diagnostician to determine if a physical sample should be sent. Arthropod identification can frequently be made by the photograph alone. It is highly recommended that FPDN First Detector training include information on digital diagnosis and the University of Florida/IFAS Extension Distance Diagnostic and Identification System (DDIS) http://ddis.ifas.ufl.edu/. All Florida Cooperative Extension offices currently have immediate access to DDIS. Through DDIS, you may choose to submit your photos to a specific lab or specialist or multiple individuals. Mapping features for pests in the DDIS system are also available. In essence, DDIS allows users to submit either a photograph or a series of photographs online without clogging inboxes with large image files. A record of the sample is also permanently logged in the DDIS system. Users may 
choose to make their sample private if they are concerned about the confidentiality of the submitter. Other samples may be viewed by any specialists logging into the system, thus increasing the number of eyes viewing and potentially identifying your sample. As of 2007, the public also has the opportunity to use DDIS for sample submission.

Educators are also encouraged to include hands-on field trips or laboratory exercises in their training. Most individuals attending this training are very field oriented, and they enjoy the face-to-face time and practicing what they learn in the classroom. Hands-on demonstrations through the DDIS website are also valuable and increase the comfort level of participants with this web interface.

Even though national core modules and content does exist, local customization is essential for First Detector training. Customization of material for your audience is particularly critical for 1) Monitoring for High Risk Pests and 2) Submitting Diagnostic Samples. First Detectors need relevant, tangible examples of pests of concern to them. Of course, it is also important for First Detectors to feel connected to their local diagnostic laboratory. Example presentations for Florida are available on the FPDN website at: http://fpdn.ifas.ufl.edu/. Even within Florida, pests of concern may vary geographically and within certain commodities. Example special topic presentations of potential use to Florida on the main NPDN website http://www.ndpn.org/ include:

- Citrus Greening

- Africanized Honeybee

- Redbay Ambrosia Beetle

- Scolytids of the Eastern U.S.

Finally, when conducting training to individuals outside of the Cooperative Extension Service, it is important to emphasize the local county extension agents as the first line of contact for suspect samples. County extension agents are very familiar with the pests in their local area, and something that may appear exotic by the untrained eye may be easily recognized at the county office. Links to the University of Florida's County Extension Offices are available at: http://solutionsforyourlife.ufl.edu/map/.

\section{Accuracy of Content and Other Resource Information for Instructors}

A train-the-trainer First Detector Educator manual is available on the NPDN First Detector Information page http://www.npdn.org/ (navigate to First Detector Information on the left menu bar). The First Detector Educator training manual is updated at least annually, but may be updated more frequently as needs arise.

All presentations include the date the material was updated. Webpage updates will occur periodically. Visit the NPDN website, http://www.npdn.org/ for the latest information. It should be noted that individuals using the material are responsible for ensuring that their content is up-to-date. All materials available through NPDN are for non-profit, educational use as long as authors, their affiliate organization, and the NPDN are appropriately credited.

\section{How can First Detector Educators Partner to Enhance Training?}

Partnering with organizations interested in invasive species issues is a vital component of First Detector training. Limited resources are available for First Detector training, and partnering enhances all of our programs. On the regional and national level, inter-agency partnerships have provided opportunities for additional grant funding to support activities associated with First Detector training.

In Florida, we are fortunate to have many specialists and agencies combating invasive species. Some partnering organizations or working groups have included the following:

- IPM Florida http://ipm.ifas.ufl.edu/

- USDA-APHIS-PPQ http://www.aphis.usda.gov/

- Florida Department of Agriculture \& Consumer Services, Division of Plant Industry (FDACS-DPI) http://www.doacs.state.fl.us/ 
- Florida Cooperative Agriculture Pest Survey Program (CAPS)

http://www.doacs.state.fl.us/pi/caps/

- Invasive Arthropod Working Group (IAWG) http://mrec.ifas.ufl.edu/lso/iawg/

- Florida Master Gardener Program http://gardeningsolutions.ifas.ufl.edu/ mastergardener/

- Florida Master Naturalist Program http://www.masternaturalist.ifas.ufl.edu/

- Florida State Agriculture Response Team (SART) http://www.flsart.org/

- UF Department of Plant Pathology http://plantpath.ifas.ufl.edu/

- UF Entomology \& Nematology Department http://entnemdept.ifas.ufl.edu/

- Florida Yards \& Neighborhoods (FYN) http://fyn.ifas.ufl.edu/

\section{How can First Detector Educators Schedule a Training Session?}

Educators interested in scheduling First Detector training should go to the NPDN Training Site http://cbc.at.ufl.edu and create a login account. You can create your own username and password. If you forget your login, there are simple instructions for resetting it. Once you have logged in, navigate to NPDN Workshop and Educator Resources, then click on the link to Create a Workshop. Until you create a workshop, you will be logged in as a student. Once you have created a workshop, your role title will change to workshop coordinator.

You may use the above site to advertise your session online, and encourage participants to register in advance of your conference online. Participants are not required to login to the training site in order to register. You can link to the session registration directly from your workshop website. Organizers also have the option of establishing class size limits and dates for closing registration. There is not an online payment system incorporated in the registration process. If you are using the website for online registration of your upcoming training event and a registration is required, you will need to direct them to send you the registration directly via check or an alternative mechanism for the cost of workshop registration. As a workshop coordinator, you can edit or delete participant data for your training session. You also have the option of uploading your participant data from an Excel spreadsheet. A word of caution: participant data upload from the Excel sheet must meet exact field requirements provided in the example. Note that the example Excel template is available for download both on the NPDN First Detector information page, http://www.npdn.org and on the NPDN Training Site during the batch upload to Excel process http://cbc.at.ufl.edu.

First Detector participant information is used for reporting purposes to the NPDN and CSREES, and you may use training data from your own sessions in your annual reporting system. Maps of participants training, and statistics of training topics covered are regularly reported to NPDN and CSREES. As the NPDN is grant-funded, some limited resources exist for conducting training. For more details regarding available FPDN funds for First Detector training, contact FPDN leader Dr. Aaron Palmateer ajp@ufl.edu.

Key benefits to those using the NPDN Training Site include:

- Online registration of participants in advance of a meeting.

- As an educator, you can review or revisit the site at any time as a reference source for the individuals you have trained.

- The NPDN First Detector program provides excellent opportunities to partner with other specialist throughout the state on invasive species education issues.

- Some limited resources are available to conduct training sessions.

- Opportunities exist to partner and secure additional funding for specific training topics of interest. 
- Free color handouts for some pests of concern may be available to First Detector Educators. Recent examples include chilli thrips, lobate lac scale, cycad scale, soybean rust, citrus greening, pink hibiscus mealybug, sudden oak death, and red palm mite.

We will continue to respond as effectively as possible to any feedback you provide. All suggestions and comments are welcome.

We are also in the process of conducting First Detector Training using the UF/IFAS Polycom system. This is a great way to get speakers to present material to your training class without incurring travel costs. Multiple sites can also receive training from one specialist using this method. Be advised when using Polycom it takes a considerable amount of planning and preparation. For more information about using Polycom successfully see the EDIS article "Videoconferencing (Polycom) Distance Education http://edis.ifas.ufl.edu/IN670 (Gillett et al, 2006).

\section{Getting Started}

Need more information to get started on First Detector training? Contact Amanda Hodges achodges@ufl.edu, Carrie Harmon clharmon@ufl.edu, Aaron Palmateer ajp@ufl.edu or Jennifer Gillett-Kaufman gillett@ufl.edu for further questions.

\section{Acknowledgements}

We thank Richard Hoenisch, Western Plant Diagnostic Network (WPDN), University of California-Davis and Greg Hodges, FDACS-DPI for their editorial. We thank all of the participants that have completed First Detector training, the extension educators lending their expertise, and all others who have collaboratively participated in this program.

\section{References}

Palmateer, A.J., C.L. Harmon, A. Hodges, N. Peres, K.R. Chung, P.D. Roberts, L.Buss, W.T. Crow, J.Xin, R.J. McGovern, J.W. Kimbrough, and M.T. Momol. 2006. http://edis.ifas.ufl.edu/PP151 (December 19, 2007).
Frank, J.H. and M.C. Thomas. 2004. Invasive Insects (Adventive Pest Insects) in Florida UF/IFAS EDIS http://edis.ifas.ufl.edu/IN503 (December 19, 2007).

Gillett, J.L., A.C. Hodges and R.K. Thomas. 2006. Videoconferencing (Polycom) Distance Education. University of Florida EDIS- Electronic Data Information Source, Extension Publication No. IN 670. http://edis.ifas.ufl.edu/IN670

Momol, T., C. Harmon, J. Marois, P. Roberts, and B. McGovern. 2007. New, Emerging, and Threatening Plant Diseases and Crop Bioscecurity UF/IFAS EDIS http://edis.ifas.ufl.edu/PP112 (December 19, 2007).

Momol, T. T. Kucharek, R. Sprenkel, J. Fletcher, and L. Halsey. 2001. Distance Diagnostic and Identification System (DDIS): A New Tool for Extension Diagnostics. UF/IFAS EDIS http://edis.ifas.ufl.edu/DDIS4 (December 19, 2007).

Stiles, C.M., M.T. Momol, P.D. Roberts, R. McMillan, R.E. Cullen, and G.W. Simone. 2002. Florida Extension Plant Disease Clinic Network. UF/IFAS EDIS (December 19, 2007). 